\title{
CONSULAR ASSISTANCE FOR NATIONALS DETAINED BY A FOREIGN GOVERNMENT: STATES' POLICIES AND PRACTISES
}

\author{
Dewi Avilia* \\ * Ministry of Foreign Affairs Republic Indonesia \\ Article Info \\ Received : 14 March 2016 | Received in revised form : 20 July 2016 | Accepted : 23 March 2017 \\ Corresponding author's e-mail : dewi.avilia@kemlu.go.id
}

\begin{abstract}
The Vienna Convention on Consular Relations of 1963 outlines the rights of a state to exercise its obligation to protect the interests of its nationals abroad. The protection given by states to their nationals is commonly referred to as consular assistance. The main objective of consular assistance is to help nationals facing difficulties abroad. In the event of an arrest, the aim of the provision of consular assistance is to protect the inalienable rights of a foreign detainee. The inalienable rights inherent to all detainees are the right to retain counsel, and to receive due process of law. Although the 1963 Convention on Consular Relations is the codification of international customary law with regard to states' practises in protecting their nationals, the practises may vary from one state to another. This paper analyses the policy and practises adopted by a state to protect its nationals detained abroad and suggests effective policies to provide consular assistance based on the reviewed state practises and policies.
\end{abstract}

Keyword: Vienna Convention on Consular Relations 1963, consular assistance, national, detainee, inalienable rights

\begin{abstract}
Abstrak
Konvensi Wina tentang Hubungan Konsuler 1963 telah menggariskan hak-hak negara untuk melaksanakan kewajibannya untuk melindungi kepentingan warga negaranya di luar negeri. Perlindungan yang diberikan oleh negara untuk warganegaranya sering disebut dengan bantuan konsuler. Tujuan utama dari bantuan konsuler adalah untuk membantu warga menghadapi kesulitan di luar negeri. Dalam hal penangkapan, tujuan pemberian bantuan konsuler adalah melindungi hak-hak asasi tahanan. Hak yang melekat mutlak untuk semua tahanan untuk mendapatkan nasihat, dan untuk menjalankan proses hukum sesuai dengan ketentuan yang berlaku. Meskipun 1963 Konvensi tentang Hubungan Konsuler adalah kodifikasi hukum kebiasaan internasional sehubungan dengan praktik negara 'dalam melindungi warga negara mereka, praktik pemberian bantuan consular dapat bervariasi dari satu negara ke negara lain. Makalah ini menganalisis kebijakan dan praktek-praktek yang diadopsi oleh negara untuk melindungi warga negaranya yang ditahan di luar negeri dan menyarankan kebijakan yang efektif untuk memberikan bantuan konsuler berdasarkan praktek negara yang diulas dan kebijakan.
\end{abstract}

Kata kunci: Konvensi Wina tentang Hubungan Konsuler 1963, bantuan kekonsuleran, warga negara, tahanan, hak asasi 


\section{INTRODUCTION}

One governmental function recognized by international customary law is to provide services known as consular services to its nationals abroad. These consular services include but are not limited to certain legal services, such as notarizing documents, acting as a civil registrar, looking for missing nationals abroad, helping destitute nationals abroad, and assisting evacuation abroad. The most important consular service is the provision to assist nationals detained by a foreign government. ${ }^{1}$

Although the 1963 Vienna Convention on Consular Relations codified international customary law with regard to consular services, the policies and practises of governments in providing consular services, particularly to their nationals detained abroad, may be different from one state to another. Certain factors influence the states' practises in providing consular assistance such as consequences faced by their nationals who violate the laws abroad, political reaction, ${ }^{2}$ press coverage, and social media posts regarding the case.

The result of research conducted by Fair Trials International, published in 2009, revealed that based on five reviewed countries (Australia, the United Kingdom, the United States, the Netherlands, and Germany), the policy and form of consular assistance for its detained nationals vary from one country to another. The most striking finding was that not all countries reviewed entitle their nationals detained abroad to consular assistance. Only Germany protects legally the rights of consular assistance. The other countries reviewed treat it as a governmental commitment policy.

In that respect, this paper aims to explore states' policies and practises in consular services, particularly the provision of assistance to nationals detained by a foreign government. In addition, this paper aims to give an explanation about the objective of consular assistance provided in Article 36 (b) of the Vienna Convention on Consular Relations 1963 (VCCR). In light of the above aims, the writer has established the main research questions as follows:

- What are the objectives of the provision of consular services for nationals detained abroad under Article 36 (b) of the Vienna Convention on Consular Relations 1963 ?

- How do states interpret and exercise their rights under the 1963 Vienna Convention on Consular Relations with regard to protecting nationals detained abroad?

- What are the roles of consular officials in helping nationals detained in the receiving country?

- What are the positive and negative impacts of consular assistance?

- Does Indonesia entitle its nationals detained abroad to consular assistance?

To respond to these questions, the writer has reviewed the policies of the United Kingdom (UK), the Netherlands, Germany, Malaysia, the United States (US), and Indonesia on consular assistance for their nationals who violate the law in a country where they reside or travel. The sources of reviewed material come from publications issued by Fair Trials International and consular guidance. In addition, the writer

1 United States Department of State, Consular Notification and Access Manual, Department of State Publication, Office of Legal Adviser and Bureau of Consular Affairs. Fourth Edition. (Washington D.C: US Department of State, 2014). https://travel.state.gov/content/dam/travel/CNAtrainingresources/CNAManual Feb2014.pdf, accessed March 1, 2016,

2 Martin Mennecke and Christian Tams, "The Right to Consular Assistance Under International Law: The LaGrand Case Before the International Court of Justice," German Yearbook of International Law 42 (1999), pp. 192-241. 
has also reviewed information from international conventions, information from the Ministry of Foreign Affairs including information on the embassy's website, decisions of domestic courts, open source publications, governments' remarks in the media, reports by international organizations, and Indonesian national law. All of the reviewed literature, laws, and media statements are available online.

The writer has chosen the UK, the US, Germany, and the Netherlands as reviewed countries in addition to Indonesia because in 2009, Fair Trials International published a comparative examination of American, British, Dutch, and German Ministries of Foreign Affairs policies and practises on consular assistance. Furthermore, those five countries also provide publicly available regulations and policies with regard to consular assistance policies on their official websites.

This paper discusses only one consular function mentioned in the 1963 Vienna Convention on Consular Relations, the provision of consular assistance for nationals detained abroad. The terms detainee and detained person used in this paper mean any person deprived of his or her personal liberty except as a result of conviction for an offence. ${ }^{3}$ Nationality in this paper refers to the legal bond between an individual and a sovereign state. ${ }^{4}$

\section{THE AIMS OF THE PROVISION OF CONSULAR SERVICES FOR NATIONALS DETAINED ABROAD}

\section{A. Vienna Convention on Consular Relations 1963: Basis of Consular Assistance}

The number of people who travel across borders has increased due to the availability of competitively priced modes of transport, the convenience of reserving accommodation anywhere around the globe due to rapid developments in information technology, the abolishment of border controls within regions such as Schengen Area countries, and the free visa policies of some Association of Southeast Asian Nations (for ASEAN nationals). Indonesian nationals are no exception. ${ }^{5}$

Let us suppose that Budi, an Indonesian national, travelled to country $\mathrm{N}$ and met someone at a party in one of the famous pubs there. The man whom he met put a small package of cocaine into Budi's pocket. Police raided the pub, and Budi was arrested for drug possession. He was aware of his legal rights under the Indonesian legal system. As such, he wanted to assert his rights and defend himself, but he did not know the language of $\mathrm{N}$ nor a competent lawyer to handle his case. Budi had no options or recourse but to communicate with the Indonesian Embassy/Consulate in country $\mathrm{N}$ to seek immediate and necessary consular assistance, such as information regarding an interpreter and lawyer.

In light of the above mentioned hypothetical case, the 1963 VCCR is significant in

${ }^{3}$ Office of the United Nations High Commissioner for Human Rights, "Chapter 8: International Legal Standards for the Protection of Persons Deprived of Their Liberty," in Human Rights in the Administration of Justice: A Manual on Human Rights for Judges, Prosecutors and Lawyers, Office of the High Commissioner for Human Rights (Geneva: United Nations, 2003), p. 318

${ }^{4}$ European Union Democracy Observatory on Citizenship, “Citizenship or Nationality?,” http://eudocitizenship.eu/databases/citizenship-glossary/terminology, accessed 7 February 2016.

${ }^{5}$ According to European Union Ambassador to Indonesia Olof Skoog statement in 2014, 8.9 million Indonesians visit Europe every year not only for holidaying but also for pursuing higher education. Accessed February 3, 2016,. Antara News. "8.9 million Indonesian travel to Europe annually." http://www. antaranews.com/en/news/96058/89-million-indonesians-travel-to-europe-annually, accessed 3 February 2016. 
that it sets out a legal framework for consular officials to provide consular assistance to their nationals when they are facing difficulties in foreign countries, e.g., the arrest of sending state nationals by receiving state authority.

Of particular interest for the rights of individuals is Article 36, which provides for certain obligations for competent authorities in the case of an arrest or detention of a foreign national, in order to guarantee the inalienable right to counsel and due process through consular notification and effective access to consular protection. ${ }^{6}$

\section{B. The Inalienable Rights of Detainees}

Today, it cannot seriously be disputed that the VCCR is self-executing. ${ }^{7}$ According to Article 36(1), the receiving states should facilitate the exercise of consular functions in relation to nationals of the sending state. The VCCR guarantees that the consular officials can freely exercise their rights under the VCCR: to access and communicate with nationals of the sending state. Further, Article 36(1)b sets out the obligation of the receiving state to inform consular officials from the sending state regarding arrest, detention, or imprisonment of nationals of the sending state, if the arrestee/ detainee/prisoner requests:

[If] he so requests, the competent authorities of the receiving State shall, without delay, inform the consular post of the sending State if, within its consular district, a national of that State is arrested or committed to prison or to custody pending trial or is detained in any other manner. Any communication addressed to the consular post by the person arrested, in prison, custody or detention shall be forwarded by the said authorities without delay. The said authorities shall inform the person concerned without delay of his rights under this subparagraph ${ }^{8}$.

The requests from nationals of the sending state to inform consular officials can be disregarded when there is a bilateral agreement between the sending and receiving states on mandatory consular notification.

The objective of Article 36(1) is to preserve the inalienable rights guaranteed by the International Covenant on Civil and Political Rights (ICCPR). The right of due process is an inalienable right guaranteed in ICCPR Article 14(1):

All persons shall be equal before the courts and tribunals. In the determination of any criminal charge against him, or of his rights and obligations in a suit at law, everyone shall be entitled to a fair and public hearing by a competent, independent and impartial tribunal established by law....

Further, article 14 (3) sets out additional rights as follows: ${ }^{10}$

In the determination of any criminal charge against him, everyone shall be entitled to the following minimum guarantees, in full equality:

(a) To be informed promptly and in detail in a language which he understands of the

${ }^{6}$ Juan Manuel Gómez Robledo, “The Vienna Convention on Consular Relations,” http://legal.un.org/ avl/ha/vccr/vccr.html, accessed 1 February 2016.

7 Yuri A. Kolesnikov, "Meddling with the Vienna Convention on Consular Relations: The Dilemma and Proposed Statutory Solutions," McGeorge Law Review 40 (2009), p. 189.

${ }^{8}$ Robledo, "The Vienna Convention."

9 International Covenant on Civil and Political Rights, New York, 19 December 1966, United Nations Treaty Series, Vol. 99, p. 171. (hereinafter referred as "ICCPR")

${ }^{10}$ Ibid. 
nature and cause of the charge against him;

(b) To have adequate time and facilities for the preparation of his defence and to communicate with counsel of his own choosing;

(g)...

The phrase all persons and the word everyone have been used in the ICCPR to emphasise that the rights should be granted indiscriminately (regardless of gender, sexual orientation, beliefs, age, and nationality).

\section{III.STATES' POLICIES ON CONSULAR SERVICES FOR NATIONALS DETAINED BY A FOREIGN GOVERNMENT: PRACTISES OF THE UK, THE NETHERLANDS, GERMANY, MALAYSIA, THE US, AND INDONESIA}

\section{A. United Kingdom}

\section{Basis of Consular Assistance}

The Consular Service is the part of the UK Government to which British nationals turn when they encounter serious problems overseas, from lost passports to kidnapping to arrest to the death of a loved one. ${ }^{11}$ The activities of consular staff are governed by international agreements, including the VCCR, or bilateral consular conventions. ${ }^{12}$ The UK is a party to the Vienna Convention and the Optional Protocol Concerning the Compulsory Settlement of Disputes, and has 32 bilateral agreements of various kinds with many states, ${ }^{13}$ under which they are to be notified automatically when one of their nationals is detained abroad. ${ }^{14}$ Nevertheless, British consular assistance is provided as a matter of government policy; it is not a legally protected right of British nationals detained overseas. ${ }^{15}$

In 2014, the British Foreign and Commonwealth Office (FCO) published Support for British nationals abroad: A guide. The publication outlines a commitment from the British Government to its nationals to provide necessary assistance abroad when help is requested. In the guidebook, the FCO explains British nationals who are eligible of consular assistance, the form of consular services, and what the FCO can and cannot do.

\section{Who Is Eligible for Consular Assistance?}

The guidebook states that only British nationals are eligible for consular assistance. A person is considered to be a British national if he or she is one of the following:

- a British citizen;

- a British Overseas Territories citizen;

- a British overseas citizen;

- a British national (overseas);

- a British subject;

11 House of Commons Affairs Committee, "Support for British national abroad: the Consular Services," Fifth Report of Session 2014-2015, http://www.publications.parliament.uk/pa/cm201415/cmselect/ cmfaff/516/516.pdf, accessed 1 March 2016.

12 Ibid.

13 United Kingdom, “Table of Consular conventions and mandatory notification obligations," https:// www.gov.uk/government/publications/table-of-consular-conventions-and-mandatory-notification-obligations, accessed 1 March 2016.

${ }^{14}$ Katerina Mantouvalou, Consular Assistance and Trial Attendance: A Comparative Examination of the American, Australian, British, Dutch and German Ministries of Foreign Affairs (London: Fair Trials International, 2009), p. 12.

${ }^{15}$ Ibid., p. 25 
- a British protected person;

- EU nationals are also eligible to receive consular assistance from a British consulate or embassy if their country of origin is not represented. ${ }^{16}$

Nevertheless, the British authority cannot provide consular assistance to all British nationals abroad. National laws where British nationals reside affect the exercise of consular assistance. British nationals (overseas) of Chinese ethnic origin in China, Hong Kong, and the Macao Special Administrative Regions are considered Chinese nationals by the Chinese authorities. As such, the British government cannot provide consular assistance to them. The Chinese authorities consider British nationals (overseas) of Chinese ethnic origin as Chinese nationals. Therefore, the British government has no power to get involved in mainland China. However, if British nationals (overseas) of Chinese ethnic origin in China are living or travelling outside China, Hong Kong, and Macao, the British government can provide consular assistance when needed.

The British government offers consular assistance for a dual British national in a third country (that is, a country of which a dual British national is not a national). A dual British national is eligible for British consular assistance, even though he or she is not travelling with a British passport. ${ }^{17}$

\section{UK Policy and Practise in Assisting British Nationals Detained Abroad by Foreign Governments}

According to the publication issued by the UK Parliament in 2014, approximately 6,000 Britons are arrested each year, and at any one time, more than 3,250 British nationals are in prison around the world. ${ }^{18}$ The support that the FCO can offer prisoners abroad is set out in Support for British nationals abroad: A guide, as well as the FCO booklet focused specifically on prisoners, In prison abroad. ${ }^{19}$ The British government forthrightly mentions in the guidebook what the FCO can and cannot do. In summary, the FCO sets out consular assistance that can and cannot be provided to British nationals who are detained abroad as follows.

The British FCO can do the following:

a. contact the detainee in prison and visit, if he or she so wishes;

b. provide information about the local legal system, legal aid schemes, prosecution, remand, bail, and the appeal procedure;

c. provide a list of local lawyers and interpreters;

d. explain about the local prison or remand system;

e. put the prisoners in touch with the prisoner welfare charity for prisoners abroad. This charity organization helps detainees who do not have any other source of income, the amount of which is usually $£ 60-100$ per quarter; ${ }^{20}$

f. tell the prisoner's family and friends, if he or she so wishes, and pass messages between them;

g. help family and friends to send money and goods to the detainee. The FCO

16 European Union, Directive No. 2015/637 of 20 April 2015 on the coordination and cooperation measures to facilitate consular protection for unrepresented citizens of the Union in third countries and repealing Decision 95/553/EC.

17 Foreign and Commonwealth Office, "Support for British nationals abroad: A guide," ttps://www. gov.uk/government/uploads/system/uploads/attachment_data/file/584047/FCO_Brits_Abroad_ web130117.pdf, accessed February 28 2016, p. 28.

18 House of Commons Affairs Committee, "Support for British national abroad: the Consular Services," Fifth Report of Session 2014-2015, http://www.publications.parliament.uk/pa/cm201415/cmselect/ cmfaff/ 516/ 51609.htm\# note112, accessed 1 March 2016.

19 Ibid.

${ }^{20}$ Mantouvalou, Consular Assistance and Trial Attendance, p. 12. 
does not charge the relatives for transferring funds up to $£ 200 .^{21}$

Furthermore, according to the UK Parliament publication, in the long term, the FCO can do the following:

a. visit the prison and keep in touch by telephone or letter;

b. consider approaching local authorities if the prisoner is not treated in accordance with internationally accepted standards;

c. take up any justified complaints about ill treatment, personal safety, or discrimination, and ensure that medical or dental problems are brought to the attention of the police or a doctor; pass money from family and friends; explain how to transfer to a prison in the UK; with the permission of the detainee, consular officials can also pursue complaints of ill treatment with prison authorities, intervening when detainees are not treated in line with internationally accepted standards, if it is appropriate in the circumstances. ${ }^{22}$

\section{Managing Expectations}

To anticipate unrealistic demands from British nationals detained by a foreign government abroad, the FCO sets out a list of services that cannot be provided to the detainee, e.g., to investigate crimes, get the Briton out of prison, prevent the local authorities from deporting the Briton, or "interfere in criminal or civil court proceedings." 23

In addition, the FCO emphasises that consular staff cannot help Britons receive better treatment in prison than local prisoners (although they may raise concerns with local authorities if treatment falls below internationally recognized standards). ${ }^{24}$

\section{B. The Netherlands \\ Basis of Consular Assistance}

One of the main responsibilities of the Dutch Minister of Foreign Affairs is to promote the interests of the Netherlands at an international level. ${ }^{25}$ This includes catering to the needs of Dutch nationals held in prison abroad.

The 1963 VCCR and bilateral consular conventions is the legal framework for Dutch consular work overseas. According to a letter from the Ministry of Foreign Affairs to Parliament in 2001, "Under existing international law, States are not formally required to provide consular assistance to their nationals in foreign countries, although they do have the right to do so." 26

Following his letter to Parliament in 2001, the Dutch Minister of Foreign Affairs wrote to Parliament in 2002 to emphasise that, "Consular assistance to Dutch nationals is one of the core tasks of the Ministry of Foreign Affairs and assistance to those in foreign detention is an important focal point."27

${ }^{21}$ Ibid.

22 Ibid.

${ }^{23}$ Foreign and Commonwealth Office, "Support for British nationals abroad," p. 3.

${ }^{24}$ Ibid.

25 Algemene Rekenkamer, Assistance to prisoners abroad (The Hague: Algemene Rekenkamer, 2005), p. 11.

${ }^{26}$ F. B. A. M. van der Meulen. Detained Abroad: Assisting Dutch Nationals on Foreign Detentions (Hertogenbosch: Uitgeverij BOXPress, 2015), p. 108, https://pure.uvt.nl/portal/files/9269711/Hofstee van der Meulen Detained 1012 2015.pdf, accessed 1 February 2016.

27 Ibid. 


\section{Innovative Policy to Reach Dutch Nationals Who Are in a State of Emergency}

To cater to the needs of Dutch travellers around the world, particularly those who are in the state of emergency, in January 2016, Foreign Minister Bert Koenders and travel expert Floortje Dessing launched a new central helpline for travellers. The Ministry of Foreign Affairs can now be reached 24 hours a day, seven days a week at +31247 247247 for practical travel tips and assistance. ${ }^{28}$ Travellers abroad can also contact the Ministry online and via Twitter. By operating through a central contact centre in The Hague, the Ministry aims to provide better and faster service to the public. ${ }^{29}$

The new services are not only for holiday travellers, but also for Dutch nationals living abroad and foreigners wanting to travel to the Netherlands. ${ }^{30}$

Although a new approach to provide better assistance to Dutch nationals abroad has been announced by the Dutch Ministry of Foreign Affairs, consular assistance is provided as a matter of government policy: it is not a legally protected right of Dutch nationals. ${ }^{31}$

\section{Who Is Eligible for Consular Assistance?}

- $\quad$ All Dutch nationals. ${ }^{32}$

- Dual (or multiple) nationals in third countries are also eligible to receive consular assistance irrespective of the passport with which they travelled. In such cases, consular officials discuss the issue with the embassy of the other nationality and the defendant, and jointly decide which embassy is better equipped to assist. ${ }^{33}$

- Residents and family members of Dutch nationals are also eligible to receive consular assistance.

- A person with refugee status who is in possession of valid Dutch residence permit can receive restricted consular assistance. ${ }^{34}$

- EU nationals are also eligible to receive consular assistance from a Dutch consulate or embassy if their country of origin is not represented. ${ }^{35}$ In this case, EU nationals receive the consular assistance as nationals. ${ }^{36}$

\section{Dutch Policy and Practise in Assisting Dutch Nationals Detained Abroad by Foreign Governments}

A total of 2,266 Dutch nationals were detained abroad in 2015. Over the last 25 years, the total number of Dutch nationals in foreign detention has exploded. ${ }^{37}$ The Dutch embassy in Kuala Lumpur's website states that 2,500 Dutch nationals are in prison abroad, mostly for smuggling drugs. ${ }^{38}$ The Dutch embassy and the Ministry

${ }^{28}$ Government of The Netherlands, "Travellers can reach foreign ministry 24/7 at +31247 247 247," https://www.government.nl/topics/dutch-nationals-in-emergency abroad/news/2016/01/12/travellers-can-reach-foreign-ministry-24-7-at-31-247-247-247/, accessed 1 March 2016.

${ }^{29}$ Ibid.

30 Ibid.

${ }^{31}$ Mantouvalou, Consular Assistance and Trial Attendance, p. 15.

${ }^{32}$ Ibid., 16

${ }^{33}$ Ibid.

${ }^{34}$ Van der Meulen, Detained Abroad, p. 1.

${ }^{35}$ European Union, Directive No. 2015/637 of 20 April 2015

${ }^{36}$ Van der Meulen, Detained Abroad, p.109.

37 Ibid., 94

38 Embassy of the Kingdom of the Netherlands in Kuala Lumpur, "What to do if you are arrested abroad," http://malaysia.nlembassy.org/shared/products-and-services/when-things-go-wrong-abroad/ what-to-do-if-you-are-arrested-abroad.html, accessed 1 March 2016. 
of Foreign Affairs can help Dutch nationals detained by a foreign government in several ways, namely as follows:

Soon after the arrest, the embassy can do the following:

- Visit detainees. According to the Ministry's guidelines, consular officials should visit detainees within 24 hours of being informed of their detention to make an initial assessment of the case and the type of assistance they might require. ${ }^{39}$

- Inform detainees how to get legal assistance from a lawyer.

- Provide information about the country's penal and judicial system.

- $\quad$ Keep in touch with the detainee's family and friends in the Netherlands.

In addition, the Dutch government can do the following:

- $\quad$ Provide direct financial aid to all detainees outside the EU. They may receive 30 Euros as a benefit each month. ${ }^{40}$

- $\quad$ Arrange visits by volunteers. ${ }^{41}$

In the Netherlands, three main organizations provide assistance to Dutch nationals detained by a foreign government. The main organizations are the Consular Affairs and Migration Policy Department of the Dutch Ministry of Foreign Affairs and the Dutch diplomatic mission, the International Office of the Dutch Probation Service, and the religious foundation Epafras. ${ }^{42}$

\section{Court Decisions on Consular Assistance for Dutch Detainees Abroad: M.K. v.} Netherlands

In 1997, Mr. Kuijt, a Dutch national, had been held in pre-trial detention in Bangkok on suspicion of drug trafficking. Despite the Dutch government's attempts to prevent this, and having exhausted all local remedies, he was convicted on predominantly circumstantial evidence. Six years later, he instituted summary proceedings to the Dutch court. He considered the pre-trial detention as a violation of his right to a fair trial within a reasonable time and his right to liberty. Mr Kuijt argued that the Dutch government had an obligation to improve his situation and claimed that the Dutch government should try everything to secure his release.

The Dutch court concluded that his complaint could not be upheld. The court stated that:

"The government was unable to dictate to the Thai government how to treat its prisoners. In addition, the Court decided that although the situation of Mr. Kuijt was a reason for concern, his claims nevertheless had to be dismissed, as they were both too farfetched and too unsubstantiated." ${ }^{\prime 3}$

The decision of the Dutch court has emphasised that the Dutch government is limited in the extent to which it can provide consular assistance to its nationals. The court decision also did not encourage the Dutch government to dictate other government acts, even though there was a reasonable concern about the ill treatment of nationals by the foreign government authority. ${ }^{44}$

\section{Managing Expectations}

\footnotetext{
${ }^{39}$ Mantouvalou, Consular Assistance and Trial Attendance, p. 16.

${ }^{40}$ Ibid., 16

${ }^{41}$ Van der Meulen, Detained Abroad, p. 110.

${ }^{42}$ Ibid.

43 Annemarieke Vermeer-Künzli, "Restricting Discretion: Judicial review of diplomatic protection," https://openaccess.leidenuniv.nl/bitstream/handle/1887/12538/06.pdf?sequence=7, accessed 1 February 2016, p. 192.

${ }^{44}$ Ibid.
} 
The Dutch government takes all necessary measures to ensure that Dutch nationals detained by a foreign government are treated in line with internationally accepted standards. The Dutch Ministry of Foreign Affairs stresses that every Dutch national should comply with the law where he or she resides, and publishes a precautionary message to prevent detention of its nationals abroad through its embassy's website.

On the Dutch embassy's website in Jakarta (Indonesian language version), the embassy emphasises that a Dutch national is subject to a country's laws and regulations while in a foreign country in which the law and legal system sometimes differ significantly from those in the Netherlands. ${ }^{45}$ In addition, the embassy sets out the role of the consul and the consular services that cannot be provided to Dutch nationals who are detained, e.g., to investigate crimes, get Dutch nationals out of prison, and pay lawyers' fees.

\section{Germany \\ Basis of Consular Assistance}

Germany is the only country in which consular assistance is a legally protected right. The Law on Consular Officers, their Functions and Powers (Consular Law) of 11 September 1974 constitutes the legal basis for consular assistance provided to German nationals abroad. ${ }^{46}$ Article 7 of the Law contains a specific provision relevant to detainees, namely as follows:

"Consular officers shall care for Germans remanded in custody pending trial or service in prison in their consular district and specially provide them with legal protection if so requested by such persons." ${ }^{47}$

Germany ratified the VCCR on September 7, 1971. In addition, Germany signed several bilateral agreements with other states regarding consular notification.

\section{Who Is Entitled to Consular Assistance?}

The German Federal Foreign Office provides consular assistance to all German nationals who are detained, imprisoned, or on trial abroad. ${ }^{48} \mathrm{~A}$ German dual national is also entitled to consular assistance. The German Federal Foreign Office will provide consular assistance to dual nationals who are detained in second or third countries. ${ }^{49}$ It also makes no difference whether the dual nationals are travelling with German passport or second country passport. ${ }^{50}$

Nevertheless, the German Federal Foreign Office cannot provide consular assistance to dual nationals if he or she is domiciled in the second country where the authorities of the second country consider the German dual national as their own national and forbids consular interference from German missions abroad. ${ }^{51}$

\section{German Policy and Practise in Assisting German Nationals Detained Abroad by Foreign Governments}

45 Kingdom of Netherland Embassy in Jakarta, "Warga Belanda di Indonesia [Netherland nationals in Indonesia]," http://indonesia-in.nlembassy.org/organization/bagian-dalam-kedutaan/konsuler/wargabelanda-di-indonesia, accessed 1 March 2016.

46 Mantouvalou, Consular Assistance and Trial Attendance, p. 18.

47 Ibid.

48 Ibid.

${ }^{49}$ Ibid.

50 Ibid.

51 Auswärtiges Amt Berlin,Informationen zu konsularischen, “FragenHilfe in Notfällen," http://www. konsularinfo.diplo.de/notfallhilfe, 1 March 2016. 
The German Consulate General in Dubai's website mentions that the consulate provides consular assistance to German nationals detained abroad. The services are as follows:

- $\quad$ Provide a list of lawyers (if necessary, with foreign language skills). ${ }^{52}$

- The consular officer may visit imprisoned German nationals in prison and correspond with them.

- The consular officer shall check the possible reasons for the arrest, whether the treatment is correct, and that food and health care are sufficient. On request, he or she shall inform the detainee's family members and relay their remittances.

German detainees are entitled to at least one prison visit a year. Consular officials also provide defendants with information leaflets on how the local legal system works, and how they can receive legal aid. ${ }^{53}$

\section{Managing Expectations}

Similar to the UK and the Netherlands, Germany also tries to manage the expectations of German nationals who turn to the embassy or consulate when they are facing problems or become victims of crime. The same rule applies to German nationals detained by a foreign government. To anticipate unrealistic requests from German nationals detained abroad, the German Consulate in Dubai issues information with regard to services that cannot be provided to detainees, such as intervening in court proceedings and acting as lawyers.

Germany's Foreign Office warns against the acquisition, possession, distribution, import and export of drugs, and all kinds of drug offenses prosecuted in the world. Even the possession of small quantities of drugs often leads to heavy sentences of life imprisonment, and in many places, absolutely excludes subsequent pardon. Such penalties have been imposed on western foreigners.

\section{Malaysia \\ Basis of Consular Assistance}

The legal framework for Malaysian consular activities is the VCCR (1963). Although Malaysia passed a law concerning diplomatic and consular officers in 1959, none of the articles in that law regulates the duties of consuls when a foreign government arrests a Malaysian national. The law only endows diplomatic and consular official powers as to oaths and notarial acts abroad and the power to fix fees.

\section{Who Is Eligible for Consular Assistance?}

According to the information that is available from the Malaysian Ministry of Foreign Affairs' website, Malaysian nationals are eligible to receive consular assistance.

\section{Malaysian Policy and Practise in Assisting Malaysian Nationals Detained Abroad by Foreign Governments}

In 2015, the Malaysian Minister of Foreign Affairs made a bold statement following the arrest of a Malaysian student, Nur Fitri Azmeer Nordin, arrested by UK police for possessing 30,000 extreme child pornographic materials. His statement defines what the Malaysian government will or will not do in order to safeguard the interests of its nationals abroad. The Malaysian Minister of Foreign Affairs reacted by saying:

${ }^{5}$ Ibid. 


\begin{abstract}
"Under no circumstances should our Malaysians abroad imagine that the government of Malaysia would step in to save them if they commit crimes abroad. He added, "Do not confuse consular services and the preservation of basic human rights with a right to be saved when committing an act deemed as a very serious and inhumane crime, especially one related to children." ${ }^{54}$
\end{abstract}

With that statement, the Malaysian government tried to emphasise that consular services for assisting Malaysian nationals detained abroad were not aimed at saving Malaysian nationals from prosecution, but at preserving the detainees' rights. Malaysian nationals who violate local laws should be held responsible and take all the consequences.

According to the Malaysia Ministry of Foreign Affairs' website, the Malaysian mission provides consular assistance for Malaysians detained abroad, such as the ability to:

- $\quad$ contact the detained person; arrange for informing family or next of kin if the detainee so wishes;

- give advice and guidance with the primary aim of helping them to help themselves and provide a list of local doctors and lawyers;

Furthermore, the Ministry of Foreign Affairs sets out what the mission will not do:

- It will not investigate crimes in a foreign country.

- $\quad$ In the event of arrest/detention of Malaysian nationals abroad, the Malaysian government will not provide legal advice, intervene in court proceedings, or provide funds to pay legal costs or fines, or do anything that is against the local law to help Malaysian nationals.

- It will not involve itself with the host government's affairs to get Malaysian nationals out of prison or to obtain special treatment in prison.

- It will not become a bailsman, guarantor, or sponsor.

\title{
Managing Expectations
}

Similar to the UK, the Netherlands, and Germany, the Malaysian Ministry of Foreign Affairs also anticipates far-fetched requests from Malaysian nationals detained by a foreign government by providing information with regard to consular assistance that cannot be provided by the mission abroad. The media statement from Malaysian Minister of Foreign Affairs Anifah Aman in response to a Malaysian national caught by UK police in 2015 emphasised that a Malaysian national who commits a gross violation of basic human rights will receive consular assistance. Nevertheless, the assistance does not aim to save him or her from prosecution.

\section{E. United States of America Basis of Consular Assistance}

The VCCR and bilateral agreement with other countries provide a legal framework for the US mission to provide consular assistance to US nationals abroad. Nevertheless, the US government does not entitle its nationals to the right of consular assistance. Similar to the Netherlands, Malaysia, and the UK, consular assistance is a matter of governmental policy.

${ }^{54}$ Channel News Asia, "Malaysia should set up paedophile registry: Foreign Minister," http://www. channelnewsasia.com/news/asiapacific/malaysia-should-set-up/1831672.html, accessed 7 January 2016. 


\section{Who Is Eligible for Consular Assistance?}

All American citizens are eligible to receive consular assistance; dual nationals who travel to a third country also receive consular assistance irrespective of the passport with which they travelled. ${ }^{55}$ According to the US Department of State's Overseas Citizens Service (DSOCS), the passport that people travel with matters only when dual nationals are in the country of their other nationality. ${ }^{56}$

\section{US Policy and Practise in Assisting US Nationals Detained Abroad by Foreign Governments}

The Bureau of Consular Affairs under the US Department of State, via its website, serves to inform US nationals with regard to the consular services provided for US nationals detained by foreign governments. These are as follows:

US missions abroad may:

- $\quad$ provide a list of local attorneys who speak English;

- contact family, friends, or employers of the detained US citizen with the citizen's written permission;

- visit the detained US citizen regularly and provide reading materials and vitamin supplements where appropriate;

- $\quad$ help ensure that prison officials are providing appropriate medical care for US nationals;

- $\quad$ provide a general overview of the local criminal justice process;

- $\quad$ inform the detainee of available local and US-based resources to assist them;

- $\quad$ if requested, ensure that prison officials permit visits with a member of the clergy of the religion of their choice;

- $\quad$ establish an Overseas Citizen Services (OCS) Trust so friends and family can transfer funds to imprisoned US citizens, when permissible under prison regulations.

The US mission abroad cannot:

- $\quad$ state to a court that anyone is guilty or innocent;

- $\quad$ get US citizens out of jail overseas;

- $\quad$ provide legal advice or represent US citizens in court overseas;

- $\quad$ serve as official interpreters or translators;

- $\quad$ pay legal, medical, or other fees for US citizens overseas.

\section{Managing Expectations}

The US Embassy in Mexico has published precautionary messages to US nationals who stay or reside in Mexico. The message is as follows:

While in a foreign country, a US citizen is subject to that country's laws and regulations, which sometimes differ significantly from those in the United States and may not afford the protections available to the individual under US law.

Persons violating Mexican laws, even unknowingly, may be expelled, arrested, or imprisoned. Penalties for possession, use or trafficking in illegal drugs in Mexico are severe, and convicted offenders can expect long jail sentences and heavy fines. If you break local laws in Mexico, your US citizenship will not help

${ }^{55}$ Mantouvalou, Consular Assistance and Trial Attendance, p. 22.

56 Ibid. 
you avoid arrest or prosecution. It is very important to know what is legal and what is illegal wherever you go. If arrested in Mexico, a US citizen must go through the foreign legal process including possible charge or indictment, prosecution, possible conviction and sentencing, and any appeals process. ${ }^{57}$

\section{F. Indonesia \\ Basis of Consular Assistance}

By the grace of God Almighty and motivated by the noble desire to live a free national life, the people of Indonesia hereby declare their independence. Subsequent thereto, to form a government of the state of Indonesia which shall protect all the people of Indonesia and all the independence and the land that has been struggled for... ${ }^{58}$

-Preamble of Constitution of Republic of Indonesia

The constitutional mandate Law Number 37 Year 1999 concerning International Relations sets out the government's obligation to provide protection and legal assistance to Indonesians abroad.

In 2008, the Minister of Foreign Affairs enacted Regulation No. 4 Year 2008 concerning Citizen Services at Indonesian Mission Abroad. The regulation contains guidance for Indonesian missions in exercising consular services, including consular assistance to Indonesian nationals detained abroad. ${ }^{59}$ The regulation was instituted based on the VCCR.

\section{Who Is Entitled to Consular Assistance?}

The principle of maximum protection is a principle that demands that the government is responsible for providing full protection to all Indonesian citizens in any situation, whether in or outside the country. ${ }^{60}$

- $\quad$ Elucidation on Law No. 12 Year 2006 concerning Indonesian Citizenship

According to Law No. 12 Year 2006, all Indonesian citizens including Indonesian dual nationals are eligible to claim protection from Indonesian diplomatic missions abroad when detained by a foreign government. Indonesian dual nationals are entitled to claim protection under Indonesian diplomatic missions abroad in the second country as long as the second country allows such claim.

57 United States Embassy \& Consulates in Mexico, "Arrest of a U.S. Citizen," https://mx.usembassy. gov/u-s-citizen-services/arrest-of-a-u-s-citizen/, accessed 1 February 2016.

58 Indonesia, The 1945 Constitution of the Republic of Indonesia, trans. International Labour Organization, http://www.ilo.org/wcmsp5/groups/public/---ed protect/---protrav/---ilo aids/documents/legaldocument/wcms 174556.pdf, accessed 1 February 2016.

59 Indonesian Ministry of Foreign Affairs in its Strategic Plan 2015-2019 has set out a goal to improve the quality of protection of Indonesian nationals abroad. Nevertheless, the Ministry's strategic plan does not mention revising the existing citizen services guide as one of its strategies to achieve the goal. See Ministry of Foreign Affairs Republic of Indonesia, Rencana Strateigs Kementerian Luar Negeri 20152019 [Strategic Plan of the Ministry of Foreign Affairs 2015-2019] (Jakarta: Kementerian Luar Negeri RI, 2015), http://www.kemlu.go.id/Documents/RENSTRA PK LKJ/RENSTRA\%20KEMENLU\%202015\%20 2019\%20FINAL\%20DONE\%20220415.pdf, accessed 1 February 2016.

${ }^{60}$ Indonesia, Undang-Undang tentang Kewarganegaraan Nomor (Law regarding Nationality), UU Nomor 12 Tahun 2006, LN No. 63 Tahun 2006 (Law Number 12 of 2006, SG No. 63 Year 2006). Penjelasan. [Elucidation]. Unofficial translation, http://www.refworld.org/pdfid/4538aae64.pdf, accessed 1 February 2016. 


\section{Indonesian Policy and practise in Assisting Indonesian Nationals Detained Abroad by Foreign Governments}

The Ministry of Foreign Affairs reiterated its aim to improve the quality of protection provided by diplomatic missions abroad by including protection of Indonesian citizens and legal entities abroad as one of its priorities.

Last year, Indonesia set four foreign policy priorities, namely as follows: 1) upholding the sovereignty of the Republic of Indonesia; 2) protecting Indonesian citizens/legal entities abroad; 3) promoting Indonesia's economic diplomacy; and 4) advancing Indonesia's regional and international role. ${ }^{61}$ -Annual press statement, H.E. Retno L.P Marsudi, Minister for Foreign Affairs Republic of Indonesia, January 7, 2016

In light of the above, the Ministry of Foreign Affairs published its Consular Guidance Book in March 2016. The second foreign policy priority states that protecting Indonesian citizens abroad is often interpreted by the public to mean that the government is obligated to free Indonesian nationals in the custody of foreign governments, or to save Indonesian nationals from prosecution when they violate the foreign country's law. ${ }^{62}$

According to the Minister of Foreign Affairs Regulation No. 4 Year 2008, consular assistance for Indonesians detained abroad is as follows:

a. contacting the detainee in prison and visit, if he or she so wishes;

b. providing information about the local legal system, legal aid schemes, prosecution, remand, bail, and appeal procedures;

c. providing a list of local lawyers and interpreters;

d. explaining about the local prison or remand system;

e. informing the prisoner's family and friends, if she or he so wishes, and passing on messages.

The regulation does not mention what Indonesian diplomatic missions abroad cannot do.

\section{Innovative Policy to Reach Indonesian Nationals Who Are in a State of Emergency}

The Ministry of Foreign Affairs launched a Short Message Service (SMS) blast in 2014 that contained the address of Indonesian diplomatic mission abroad and the hotline number that can be contacted 24 hours a day, seven days a week by Indonesian nationals in a state of emergency.

\footnotetext{
61 Ministry of Foreign Affairs Republic of Indonesia, "The Annual Press Statement of the Indonesian Minister for Foreign Affairs 2016," http://www.kemlu.go.id/en/pidato/menlu/Pages/The-Annual-PressStatement-of-the-Indonesian-Minister-for-Foreign-Affairs-2016.aspx, accessed 1 February 2016.

${ }^{62}$ Member of Commission IX of the House of Representatives of the National Mandate Party (F - PAN) Daulay Partaonan Saleh asked the government to immediately find a solution to free Krisdianti from such punishment. That statement was made by Saleh Partaonan Daulay in response to Penang Court decision to sentence Indonesian national, Rita Krisdianti, with death penalty for bringing drugs to Malaysia; Septianto, Bayu, "Pemerintah Harus Cari Solusi Bebaskan TKI Rita dari Hukuman Mati [The Government Must Find a Solution to Save Indonesian Female Migrant Worker from the Death Sentence]." Okezone.com, May 31, 2016, http://news.okezone.com/read/2016/05/31/337/1401964/pemerintah-harus-cari-solusi-bebaskantki-rita-dari-hukuman-mati, accessed 15 July 2016.
} 


\section{THE IMPACT OF CONSULAR ASSISTANCE ON A NATIONAL DETAINED BY FOREIGN GOVERNMENT}

\section{A. The Role of Consular Officials in the Event that a National of a Sending State Is Arrested, Committed to Prison, in Custody Pending Trial or Is Detained in Any Other Manner}

\section{Ensuring the Detainee Receives Adequate Information Regarding the Local Legal System, Legal Aid Scheme, Prosecution, and the Appeal Procedure}

No one anticipates being arrested while living or travelling abroad. Being arrested by a foreign authority is anybody's nightmare. Even a recidivist felon might dither upon being arrested and interrogated by foreign police or foreign authorities who are unable to speak the detainee's language.

Language is not the only factor that makes foreign detainees recoil from arrest. Foreign detainees most fear the absence of information regarding the local legal system and prosecution. "Will the police officer harm me? Will fairness prevail? Will I be locked up forever? Can I return to my country?" Those questions are most likely to linger in the mind of a person detained by foreign police or authorities.

The role of consular officials, if the detainee requests, is to provide adequate information regarding the local legal system, legal aid schemes, list of lawyers and interpreters, prosecution, and the appeal procedure. This information can help the detainee understand the rights inherent to him or her guaranteed by local laws and the ICCPR. ${ }^{63}$

\section{Informing the Family and Friends of Detainees}

When a receiving state's authorities detain a national of a sending state, it is important to inform his or her family and friends if the detainee so wishes. Prison Service in the UK has long recognised the importance of maintaining family ties. Family support is likely to improve general prisoner wellbeing, and can contribute to the prevention of suicide and/or self-harm. ${ }^{64}$

\section{Ensuring That Detainees Are Treated in Line with Internationally Accepted Minimum Standards}

Consular officials also pursue complaints about ill treatment by prison authorities and intervene when detainees are not treated in line with internationally accepted minimum standards. Nevertheless, the practises from one country to another country can differ. ${ }^{65}$

In order to pursue complaints about ill treatment by prison authorities, UK consular officials need consent from the detainee. ${ }^{66}$ Meanwhile, to pursue such complaints Indonesia, ${ }^{67}$ Australia and the Netherlands do not need the detainee's consent.

${ }^{63}$ There are few nations that are not party. Nevertheless, the terms of the ICCPR provide guidance as to the content of the fundamental rights that non-party is obligated to respect, based on non-party's participation in the United Nations and the universally binding character of such rights.

${ }^{64}$ Alice Mills, “'Great Expectations?': A Review of the Role of Prisoners' Families in England and Wales,” British Society of Criminology, http://www.britsoccrim.org/volume7/001.pdf, accessed 14 July 2016, p. 2.

65 Neither the Universal Declaration on Human Rights (UDHR), nor the ICCPR define torture or the other forms of ill treatment. A definition of torture was provided for in Article 1 of the 1975 UN General Assembly Declaration on the Protection of All Persons from Being Subjected to Torture and Other Cruel, Inhuman or Degrading Treatment or Punishment while the other forms of ill treatment were left undefined.

${ }_{66}$ Mantouvalou, Consular Assistance and Trial Attendance, p. 14.

${ }^{67}$ Indonesia, Ministry of Foreign Affairs, Peraturan Menteri tentang Pelayanan Warga pada Perwakilan Republik Indonesia di Luar Negeri (Ministerial Regulation on Service of Citizen in Representative of the Re- 


\section{Providing Moral Support to the Defendant}

According to research conducted by Fair Trials International (2009), it was revealed that Dutch and American consulates underlined that the main purpose of consular assistance, especially in terms of attending trials, is to provide moral support to the defendant and to check on their mental and physical state. ${ }^{68}$ However, according to that report, the British consulate did not consider that providing moral support was within their role.

In the case of Indonesia, neither the Minister of Foreign Affairs Regulation No. 4 Year 2008 nor the Consular Guidance Book explains the main purpose of attending trial. The regulation only mentions that diplomatic and consular agents should attend the trial. ${ }^{69}$

\section{Demonstrating the Interests of the Government of a Sending State in a Trial}

According to United States Foreign Affairs manual 7 FAM 451 Policy on Attendance, the attendance of consular officials in a trial is to show that the US has a legitimate interest in the case. However, the manual leaves it up to the US embassy or consulate to determine the degree to which a consular official will attend the trial of a US citizen or national prisoner. ${ }^{70}$ The British and German consulates mention the same reason. The Dutch consulate explicitly stated that they "do not attend trials for this reason."71 When Dutch officials attend trials they do not introduce themselves to the judges and or attend in an official capacity. On the other hand, American officials said that the first time they attend a trial they introduce themselves to the court's clerk, and they believe that the clerk passes this information to the judge. ${ }^{72}$

\section{B. The Impact of the Implementation of Consular Assistance on Detainees: The Advantages and Disadvantages of Consular Assistance}

To date, there is no research publicly available that presents the positive impact of all forms of consular assistance on influencing the treatment of government or authority of a receiving state to nationals of a sending state and the sentence itself. Fair Trials International conducted the only research regarding consular assistance to examine its advantages and disadvantages of in trial attendance. The results of the research revealed that the most important perceived benefits of trial attendance were ensuring the emotional and physical welfare of defendants. Furthermore, the research discovered that a link between trial attendance and the fairness of proceedings was unclear, although German and US consulates feel there is at least some benefit in terms of both the fairness of the trial and the conduct of the defence lawyer. ${ }^{73}$

In addition to the above, United States Foreign Affairs manual 7 FAM 451 mentions that consular assistance in the form of attending trials and hearing provides some advantages including the following:

(1) it helps ensure that there is no discrimination against the US citizen or national arrestees based on their US nationality, either in procedure or sentence;

(2) it shows the US citizen or national arrestee, and the local government, that

public Indonesia Abroad), Peraturan Menteri Nomor 4 tahun 2008 (Ministerial Regulation No. 4 of 2008).

${ }^{68}$ Mantouvalou, Consular Assistance and Trial Attendance, p. 57.

${ }_{69}$ To date there is no publicly available research with regard to the practice of Indonesian consular assistance.

${ }^{70}$ United States Department of State, "Foreign Affairs Manual 7 FAM 450 Trial, Appeals, Sentences, Post Sentencing, https://fam.state.gov/fam/07fam/07fam0450.html, accessed 15 July 2015.

${ }^{71}$ Mantouvalou, Consular Assistance and Trial Attendance, p. 57.

${ }^{72}$ Ibid.

73 Ibid. 
the United States has a legitimate interest in the case;

(3) it enables consular officials to accurately report the proceedings first-hand, not only to the Department, but also to family members, Congressional representatives, and others, consistent with the Privacy Act;

(4) it improves consular officials' knowledge of the judicial system in the host country;

(5) allows consular officials to monitor the conduct and capabilities of local attorneys; and

(6) it facilitates contact with the host government's authorities.

Besides the benefits of trial attendance, Fair Trials International's research also stated that trial attendance has certain major disadvantages. The main disadvantage of consular attendance at trial were that it was resource-intensive and time-consuming, and had a potentially negative impact on diplomatic relations and, in some cases, the trial process itself. ${ }^{74}$

In addition to that, the Fair Trials International's research revealed a drawback of trial attendance. Namely, trial attendance makes families become overly dependent on consular support and regard them as part of the legal team. ${ }^{75}$

\section{CONCLUSIOYCAND RECOMMENDATIONS \\ Conclusions}

1. The aim of establishing consular assistance is to safeguard the inalienable rights of detainees, e.g., the rights to legal counsel and due process of law, not to save or free sending state nationals from prosecution. Nevertheless, one of the main purposes of consular assistance in some countries such as the US and the Netherlands is to provide moral support to the detainees, especially at the time they are facing trial.

2. All countries, (the UK, the Netherlands, Germany, Malaysia, the US, and Indonesia) acknowledge that the 1963 VCCR set out their obligations to protect their nationals. According to their policies and domestic regulations, all states must respect the limitations set out in the VCCR when exercising the right to protect their nationals.

3. The Netherlands is the only state reviewed that provides consular assistance to residents and family members of Dutch nationals. A person with refugee status who is in possession of a valid Dutch residence permit can receive restricted consular assistance.

4. Germany and Indonesia are two countries that entitle their nationals detained abroad the rights of consular assistance.

5. Indonesia is the only country out of the six reviewed that does not provide public information about the type of assistance which cannot be provided to nationals detained abroad. The Indonesian government's decision not to publish the limitations of consular assistance could potentially create high public expectation (see p.18).

6. The standard consular services provided by all countries consist of visiting the detainee and providing a list of lawyers. Some countries (UK and the Netherlands) provide financial aid to their nationals detained abroad.

\footnotetext{
${ }^{74}$ Ibid.

75 Ibid., p. 35
} 
7. To date, there is no research publicly available that presents the positive impact of all forms of consular assistance in influencing the treatment of governments or authorities of receiving states to nationals of sending states and the sentence itself. Fair Trials International conducted the only research regarding consular assistance to examine the advantages and disadvantages of consular assistance in terms of trial attendance. The only country that claimed advantages of trial attendance was the US. The result of the research revealed that the most important perceived benefit of trial attendance was ensuring the emotional and physical welfare of defendants. Furthermore, the research discovered that a link between trial attendance and the fairness of proceedings was unclear, although German and US consulates feel there is at least some benefit in terms of both the fairness of the trial and the conduct of the defence lawyer.

8. Although the results of the research conducted by Fair Trials International show that consular assistance in the form of trial attendance has certain advantages, some disadvantages were also found. Apart from the fact that it was resourceintensive and time-consuming, it also had a potential negative impact on diplomatic relations and, in some cases, even on the trial process itself.

\section{Recommendations}

1. States should explicitly define the aims of consular assistance, in particular, to nationals detained by a foreign government to avoid unrealistic requests.

2. Consular guidance should be publicly available enabling nationals to understand their rights and obligations as well as the limitations of consular officials in providing assistance in the event of arrest of nationals abroad.

3. It is important to further review consular assistance policies and/or regulatory applications through quantitative research in order to identify the most effective form of consular assistance. 


\section{Bibliography}

\section{Legal Documents}

International Covenant on Civil and Political Rights. New York, 19 December 1966, United Nations Treaty Series, Vol. 99.

Indonesia. The 1945 Constitution of the Republic of Indonesia.

---. Undang-Undang tentang Kewarganegaraan Nomor (Law regarding Nationality). UU Nomor 12 Tahun 2006, LN No. 63 Tahun 2006 (Law Number 12 of 2006, SG No. 63 of 2006).

---. Undang-Undang tentang Hubungan Luar Negeri (Law on the International Relations). Undang-undang Nomor 37 tahun 1999, LN No. 156 tahun 1999 (Law No. 37 of 1999, SG no. 156 of 1999).

---, Ministry of Foreign Affairs. Peraturan Menteri tentang Pelayanan Warga pada Perwakilan Republik Indonesia di Luar Negeri (Ministerial Regulation on Service to Citizen in Representative of the Republic Indonesia Abroad). Peraturan Menteri Nomor 4 tahun 2008 (Ministerial Regulation No. 4 of 2008).

European Union. Directive No. 2015/637 of 20 April 2015 on the coordination and cooperation measures to facilitate consular protection for unrepresented citizens of the Union in third countries and repealing Decision 95/553/EC.

\section{Books}

Algemene Rekenkamer. Assistance to prisoners abroad. The Hague: Algemene Rekenkamer, 2005. p. 11.

Mantouvalou, Katerina. Consular Assistance and Trial Attendance: A Comparative Examination of the American, Australian, British, Dutch and German Ministries of Foreign Affairs. London: Fair Trials International, 2009.

Ministry of Foreign Affairs Republic of Indonesia. Rencana Strateigs Kementerian Luar Negeri 2015-2019 [Strategic Plan of the Ministry of Foreign Affairs 20152019]. Jakarta: Kementerian Luar Negeri RI, 2015. http://www.kemlu. go.id/Documents/RENSTRA PK LKJ/RENSTRA\%20KEMENLU\%20 2015\%202019\%20FINAL\%20DONE\%20220415.pdf. Accessed 1 February 2016.

Office of the United Nations High Commissioner for Human Rights. "Chapter 8: International Legal Standards for the Protection of Persons Deprived of Their Liberty." In Human Rights in the Administration of Justice: A Manual on Human Rights for Judges, Prosecutors and Lawyer. Office of the High Commissioner for Human Rights, 315-370. Geneva: United Nations, 2003.

United States Department ofState.Consular Notification and Access Manual,Department of State Publication, Office of Legal Adviser and Bureau of Consular Affairs. Fourth Edition. Washington D.C: US Department of State, 2014. https://travel.state.gov/content/dam/travel/CNAtrainingresources/ CNAManual Feb2014.pdf, accessed March 1, 2016.

van der Meulen, F. B. A. M. Detained Abroad: Assisting Dutch Nationals on Foreign Detentions. Hertogenbosch: Uitgeverij BOXPress, 2015. 


\section{Articles}

Alice Mills, “'Great Expectations?': A Review of the Role of Prisoners' Families in England and Wales," British Society of Criminology, http://www. britsoccrim.org/volume7/001.pdf, accessed 14 July 2016, p. 2.

Kolesnikov, Yuri A. "Meddling with the Vienna Convention on Consular Relations: The Dilemma and Proposed Statutory Solutions." McGeorge Law Review 40 (2009): 180-225.

Mennecke, Martin and Christian Tams. "The Right to Consular Assistance Under International Law: The LaGrand Case Before the International Court of Justice." German Yearbook of International Law 42 (1999): 192-241.

Vermeer-Künzli, Annemarieke. "Restricting Discretion: Judicial review of diplomatic protection." https://openaccess.leidenuniv.nl/bitstream/ handle/1887/12538/06.pdf? sequence=7. Accessed 1 February 2016.

\section{Websites}

Antara News. "8.9 million Indonesian travel to Europe annually." http://www. antaranews.com/en/news/96058/89-million-indonesians-travel-toeurope-annually. Accessed 3 February 2016.

Auswärtiges Amt Berlin,Informationen zu konsularischen. "FragenHilfe in Notfällen." http://www.konsularinfo.diplo.de/notfallhilfe. 1 March 2016.

Channel News Asia. "Malaysia should set up paedophile registry: Foreign Minister." http://www.channelnewsasia.com/news/asiapacific/malaysia-shouldset-up/1831672.html. Accessed 7 January 2016.

Embassy of the Kingdom of the Netherlands in Kuala Lumpur. "What to do if you are arrested abroad." http://malaysia.nlembassy.org/shared/productsand-services/when-things-go-wrong-abroad/what-to-do-if-you-arearrested-abroad.html, accessed 1 March 2016.

Embassy of the Netherland in Jakarta. "Warga Belanda di Indonesia [Netherland nationals in Indonesia]." http://indonesia-in.nlembassy.org/ organization/bagian-dalam-kedutaan/konsuler/warga-belanda-diindonesia. accessed 1 March 2016.

European Union Democracy Observatory on Citizenship. "Citizenship or Nationality?" http://eudo-citizenship.eu/databases/citizenship-glossary/ terminology. Accessed 7 February 2016.

Foreign and Commonwealth Office. "Support for British nationals abroad: A guide." ttps://www.gov.uk/government/uploads/system/uploads/ attachment_data/file/584047/FCO_Brits_Abroad_web130117.pdf. accessed February 28 2016, p. 28.

Government of The Netherlands. "Travellers can reach foreign ministry $24 / 7$ at +31 247247 247." https://www.government.nl/topics/dutch-nationals-inemergency abroad/news/2016/01/12/travellers-can-reach-foreignministry-24-7-at-31-247-247-247/, accessed 1 March 2016.

House of Commons Affairs Committee, "Support for British national abroad: the Consular Services." Fifth Report of Session 2014-2015. http:// www.publications.parliament.uk/pa/cm201415/cmselect/ 
cmfaff/516/51609.htm\#note112. Accessed 1 March 2016.

House of Commons Affairs Committee. "Support for British national abroad: the Consular Services." Fifth Report of Session 2014-2015, http://www. publications.parliament.uk/pa/cm201415/cmselect/cmfaff/516/516. pdf. accessed 1 March 2016.

Ministry of Foreign Affairs Republic of Indonesia. "The Annual Press Statement of the Indonesian Minister for Foreign Affairs 2016." http://www. kemlu.go.id/en/pidato/menlu/Pages/The-Annual-Press-Statementof-the-Indonesian-Minister-for-Foreign-Affairs-2016.aspx, accessed 1 February 2016.Robledo, Juan Manuel Gómez. "The Vienna Convention on Consular Relations." http://legal.un.org/avl/ha/vccr/vccr.html. Accessed 1 February 2016.

Septianto, Bayu. "Pemerintah Harus Cari Solusi Bebaskan TKI Rita dari Hukuman Mati [The Government Must Find a Solution to Save Indonesian Female Migrant Worker from the Death Sentence]." Okezone.com, May 31, 2016, http://news.okezone.com/read/2016/05/31/337/1401964/ pemerintah-harus-cari-solusi-bebaskan-tki-rita-dari-hukuman-mati. accessed 15 July 2016.

United Kingdom Government. "Table of Consular conventions and mandatory notification obligations." https://www.gov.uk/government/ publications/table-of-consular-conventions-and-mandatorynotification-obligations. Accessed 1 March 2016.

United States Department of State. "Foreign Affairs Manual 7 FAM 450 Trial, Appeals, Sentences, Post Sentencing." https://fam.state.gov/ fam/07fam/07fam0450.html. Accessed 15 July 2015.

United States Embassy \& Consulates in Mexico. "Arrest of a U.S. Citizen." https:// mx.usembassy.gov/u-s-citizen-services/arrest-of-a-u-s-citizen/. Accessed 1 February 2016. 